\title{
Efek Proteksi Disfungsi Sel Endotel Ekstrak Terpurifikasi Daun Surian (Toona sureni BL. Merr) yang Diinduksi dengan Larutan $\mathrm{NaCl}$ pada Mencit Jantan
}

(Effect of purified Endotel Extract Cell Disfunction Protection Surian Leaf (Toona sureni BL. Merr) which is Induced with $\mathrm{NaCl}$ Solution in Male Micey)

\author{
Suhatri*, Amri Bachtiar, \& Ani Puji Astuti
}

Fakultas Farmasi Universitas Andalas, Jl. Universitas Andalas, Limau Manis, Padang, Sumatera Barat 25163, Indonesia

ABSTRACT: In this study endothelial cell dysfunction in male white mice were examined. Endothelial cell dysfunction is indicated by low levels of $\mathrm{NO}$ and can cause hypertension. Endothelial cell dysfunction was induced by administering $\mathrm{NaCl} 3 \%$. In this study, purified extract of Toona sureni leaves 5, 10, and $20 \mathrm{mg} / \mathrm{kg}$ BW were administered orally for 21 days along with $\mathrm{NaCl}$. NO Serum levels were observed as the study parameter. The results showed that the administration of purified extract of $T$ sureni leaves can protect endothelial cells dysfunction induced by $\mathrm{NaCl} 3 \%$, which marked by increasing of male white mice nitrogen monoxide levels. In addition, it shows significantly different $<0$ 05compared to levels of NO positive control mice (administered $\mathrm{NaCl} 3 \%$ only). Moreoveer, The administration of purified extract of surian leaves did not affect the ratio of heart, kidney and liver weight of the on the study animal ( $p>0.05)$.

Keywords: purified extract; T sureni; dysfunction cell endothelial; $\mathrm{NaCl}$; nitric oxyde.

ABSTRAK: Pada penelitian ini diteliti disfungsi sel endotel pada mencit putih jantan. Disfungsi sel endotel ditunjukkan dengan rendahnya kadar NO dan dapat menyebabkan hipertensi. Disfungsi sel endotel diinduksi dengan pemberian $\mathrm{NaCl} 3 \%$. Pada penelitian ini digunakan dosis ekstrak terpurifikasi daun Toona sureni $(5,10,20) \mathrm{mg} / \mathrm{kg}$ BB yang diberikan secara oral selama 21 hari bersamaan dengan $\mathrm{NaCl}$. Para meter yang diamati adalah kadar $\mathrm{NO}$ dalam serum. Hasil penelitian menunjukan bahwa pemberian ekstrak terpurifikasi daun $T$ sureni terbukti dapat memproteksi disfungsi sel endotel diinduksi $\mathrm{NaCl} 3 \%$, ditandai dengan meningkatkan kadar nitrogen monoksida mencit putih jantan dibandingkan kadar NO mencit kontrol positif (hanya diberi $\mathrm{NaCl} 3 \%$ ) dan berbeda nyata $\mathrm{p}<0,05$. Pemberian ekstrak terpurifikasi daun surian tidak mempengaruhi rasio berat organ jantung, ginjal dan hati, hewan uji ( $p>0,05)$.

Kata kunci: ekstrak terpurifikasi; T sureni; disfungsi sel endotel; $\mathrm{NaCl}$; nitric oxyde.

\section{Pendahuluan}

Sel endotel merupakan konstituen dasar pembuluh darah. Sel endotel mempunyai peran yang sangat penting untuk mengatur tonus pembuluh darah yaitu dengan melepaskan Endothelium Derived Relaxing Factor (EDRF) dan Endothelium Derived Contracting Factor (EDCF) sehingga dapat mempertahankan tekanan darah yang normal. Sel endotel juga berperan pada migrasi dan pertumbuhan dari sel otot polos pembuluh darah, menghambat proses koagulasi darah dan merangsang disolusi pembekuan darah yang telah terbentuk pada lumen pembuluh darah, dan mengatur adesi dan migrasi sel-sel radang pada dinding pembuluh darah [1].

Disfungsi endotel yaitu terjadi perubahan secara reversible status fungsional sel endotel berupa respon terhadap rangsangan lingkungan. Disfungsi endotel menyebabkan penurunan sintesis nitrogen monoksida dan terjadi gangguan vasodilatasi. Disfungsi endotel sangat penting pada patogenesis penyakit pembuluh darah [2]. Dalam penelitian lain, diketahui bahwa konsumsi garam yang tinggi (20-23 g/hari) pada manusia dapat menurunkan kadar NO dalam darah [4]. Penelitian yang dilakukan oleh Jawi dan Sutirta (2012) menunjukkan konsumsi garam tinggi (konsentrasi $2 \%$ selama 2 minggu) dapat meningkatkan tekanan darah tikus. Penelitian lainnya oleh Saidu, et. al 2012 [3] menunjukkan pemberian Accepted: 28 Mei 2019

\section{Article history}

Received: 14 Mei 2019 Published: 30 Mei 2019

Access this article

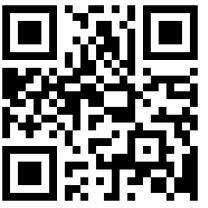


$\mathrm{NaCl} 8 \%$ selama 3 minggu dapat meningkatkan tekanan darah. Hal ini mengakibatkan terjadinya disfungsi endotel yang ditunjukkan dengan rendahnya kadar NO tikus dan menginisiasi terjadinya hipertensi esensial.

Pada hipertensi, terjadi penurunan sintesis dan pelepasan NO yang mengakibatkan penurunan respons asetilkolin sebagai endothelium depenent relaxation. Hipertensi juga menginduksi stres oksidatif pada dinding vaskuler. Radikal superoksid dapat merusak NO sehingga terjadi penarikan sel mononuklear ke dalam subendotel dan menyebabkan terjadinya plak aterosklerotik dan menginduksi progresifitas plak [4]. Pemberian antioksidan akan mengurangi radikal bebas sehingga tidak terjadi stres oksidatif dan pada akhirnya meningkatkan bioavailibilitas NO.

Beberapa penelitian terdahulu diketahui bahwa $T$ sureni mengandung senyawa flavonoid (kuersetin), terpenoid (tetranortriterpenoid yaitu surenon dan surenin) (Kraus, 1979), karotenoid, saponin [5]. Penelitian terhadap T sureni juga menyebutkan bahwa daun tanaman ini mengandung metil galat yang memiliki bioaktivitas antibakteri dan antioksidan [6]. Suhatri, Arifin dan Hadira 2009 [6] melapokan ekstrak etanol T sureni memiliki efek proteksi terhadap disfungsi sel endotel pembuluh darah tikus yang diinduksi dengan makanan lemak tinggi. Ekstrak terpurifikasi T sureni. Merr) juga memiliki aktivitas terhadap disfungsi sel endotel tikus hiperkolesterol [7] .Fraksi etillasetat $T$ sureni juga memiliki efek proteksi terhadap disfungsi sel endotel tikus hiperkolesterol terhadap aterosklerosis [8]. Penelitian terbaru juga telah mengisolation dan mengevaluasi efek proteksi metil galat T sureni dari aterosklerosis pada kedaaan hiperkolesterol pada tikus [9].

Meski penelitian mengenai efek farmakologi $T$ sureni telah banyak dilakukan, penelitian mengenai efek ekstrak terpurifikasi $T$ sureni terhadap disfungsi sel endotel yang diinduksi dengan $\mathrm{NaCl}$ belum pernah dilakukan. Hal inilah yang mendorong untuk dilakukannya penelitian efek ekstrak terpurifikasi $T$ sureni terhadap disfungsi sel endotel mencit yang diinduksi $\mathrm{NaCl}$. Parameter yg diamati adalah kadar NO.

\section{Metode Penelitian}

\section{Hewan Percobaan}

Hewan percobaan yang digunakan adalah tikus putih jantan yang berumur 2 - 3 bulan dengan berat badan 200 - 300 gram sebanyak 25 ekor.

\section{a. Penyiapan Ekstrak Terpurifikasi T sureni.}

Ekstrak terpurifikasi $T$ sureni dibuat dari serbuk $T$ sureni yang telah dikering anginkan dengan cara maserasi dengan pelarut etanol $95 \%$. Ekstrak kental etanol difraksinasi dengan pelarut non polar (fraksi heksan, semi polar (fraksi etil asetat) dan polar. Fraksi etil asetat dari daun surian dikromatografi kolom dengan fasa diam silika gel dan fasa geraknya kombinasi pelarut n-heksana, etil asetat dan metanol yang ditingkatkan kepolarannya secara Step Gradien Polarity (SGP) dengan berbagai perbandingan. Subfraksi dimonitor dengan KLT, Rf yang sama dengan pembanding digabung kemudian ditentukan beratnya dan di uji secara kuantitatif dengan KLT densitometer menggunakan pembanding metil galat (Departemen Kesehatan Republik Indonesia, 2008).

\section{b. Perlakuan Pada Hewan Percobaan}

Hewan yang digunakan adalah tikus putih jantan dengan umur 2-3 bulan dengan berat badan 20-30 g sebanyak 25 ekor. Hewan diberikan ekstrak T sureni dosis $5 \mathrm{mg} / \mathrm{kg} \mathrm{BB}, 10 \mathrm{mg} \mathrm{kg} \mathrm{BB}$, dan 20mg/kg BB selama 21 hari. Sebelum diberi ekstrak terpurifikasi $T$ sureni mencit diberi larutan $\mathrm{NaCl} 3 \%$. Setelah perlakuan selama 21 hari, hewan percobaan dikorbankan dan diambil darahnya untuk mendapatkan serumnya. Selanjutna dilakukan pengukuran kadar nitrogen monoksida (NO) dalam serum.

\section{c. Pemeriksaan Kadar NO Serum}

Pemeriksaan kadar NO serum dilakukan dengan menggunakan Kit Assay Total Nitric Oxide Assay ${ }^{\circledR}$ dan alat Ensyme-Linked Immunosorbent Assay (ELISA) produksi BioRad.

\section{d. Analisa Data}

Data yang didapatkan dari kadar nitrogen monoksida (NO) akan dianalisis secara statistik ANOVA satu arah dan dilanjutkan dengan uji Duncan, kebermaknaan akan diambil pada tingkat kepercayaan 95\% menggunakan program SPSS 21 (Jones, 2010).

\section{Hasil dan Diskusi}

Perolehan dan Pemeriksaan Ekstrak Terpurifikasi T sureni

Sebanyak \pm 50 gram fraksi etil asetat daun T sureni di kromatografi kolom flash, diperoleh 11,851 gram ekstrak terpurifikasi T sureni $(23,702 \%$ ) (Tabel 1).

Ekstrak terpurifikasi $T$ sureni berbentuk ekstrak kental berwarna hijau tua, berbau khas, dan berasa pahit. Pemriksaan dengan plat KLT silika SF 60 menunjukkan nilai Rf yang sama dengan metil galat yaitu 0,57 dengan eluen n-heksan : etil asetat (2:3) (Gambar 1). Ekstrak terpurifikasi $T$ sureni memiliki absorban maksimum 0,429 
pada panjang gelombang $\lambda 276 \mathrm{~nm}$.

Penentuan Kadar Metil Galat dalam Ekstrak Terpurifikasi T. sureni

Penentuan kadar metil galat dalam ekstrak $T$ sureni terpurifikasi menggunakan metode KLT densitometri dengan senyawa pembanding metil galat murni, diperoleh panjang gelombang maksimum standar metil galat pada 275 $\mathrm{nm}$ menggunakan spektrofotometer UV-Vis. Pembuatan kurva kalibrasi dengan larutan konsentrasi bertingkat 2; 3; 4; 5; dan 7,5 $\mu \mathrm{L} / \mathrm{ml}$ diperoleh persamaan regresi linier $\mathrm{y}=1547,3 \mathrm{x}-206,7$ dengan nilai koefisien korelasi (r) 0,9994. Hasil perhitungan kadar metil galat dalam ekstrak terpurifikasi sebesar 0,01132 g/100 g ekstrak terpurifikasi.

Pengaruh Pemberian Ekstrak Terpurifikasi T. sureni terhadap Konsentrasi Nitrogen Monoksida

Hasil pengukuran kadar NO rata-rata kelompok negatif 47,865 $\mu \mathrm{mol} / \mathrm{L}$, kontrol positif 31,943 $\mu \mathrm{mol} / \mathrm{L}$, dosis ekstrak terpurifikasi daun surian $5 \mathrm{mg} / \mathrm{kg}$ BB 46,926 $\mu \mathrm{mol} / \mathrm{L}$, dosis ekstrak terpurifikasi daun surian $10 \mathrm{mg} / \mathrm{kg}$ BB 40,511 $\mu \mathrm{mol} / \mathrm{L}$, dan dosis ekstrak terpurifikasi daun

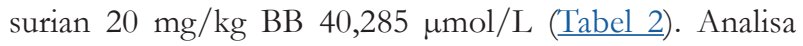

secara statistik menunjukkan bahwa kadar NO rata-rata kelompok negatif lebih besar dibandingkan kontrol positif dan berbeda nyata $\mathrm{p}<0,05$, dosis ekstrak terpurifikasi daun surian $5 \mathrm{mg} / \mathrm{kg}$ BB memberikan peningkatan kadar NO yang berbeda nyata bila dibandingan dengan kelompok kontrol positif $(\mathrm{p}<0,05)$, sedangkan dosis $10 \mathrm{mg} / \mathrm{kg}$ $\mathrm{BB}$ dan dosis $20 \mathrm{mg} / \mathrm{kg}$ BB memberikan peningkatan kadar NO tetapi secara statistik tidak berbeda nyata bila dibandingkan dengan kelompok kontrol positif $(p>0,05)$ (Tabel 3 dan gambar 2).

Pengaruh Pemberian Ekstrak Terpurifikasi T. sureni terhadap Rasio Berat Organ

a. Rasio berat organ hati

Rata-rata rasio berat organ hati tikus kelompok kontrol positif $(3,168 \pm 0,129)$, kontrol negatif $(3,127 \pm$ $0,276)$, dosis $5 \mathrm{mg} / \mathrm{kg} \mathrm{BB}(3,153 \pm 0,642)$, dosis $10 \mathrm{mg} /$ $\mathrm{kg} \mathrm{BB}(3,075 \pm 0,245)$, dan dosis $20 \mathrm{mg} / \mathrm{kg} \mathrm{BB}(3,431$ $\pm 0,451)$. Berdasarkan analisa secara statistik, pemberian ekstrak terpurifikasi daun surian tidak memberikan pengaruh terhadap rasio berat organ hati tikus uji $(\mathrm{p}>$ $0,05)$ (Tabel 3 dan gambar 3 .

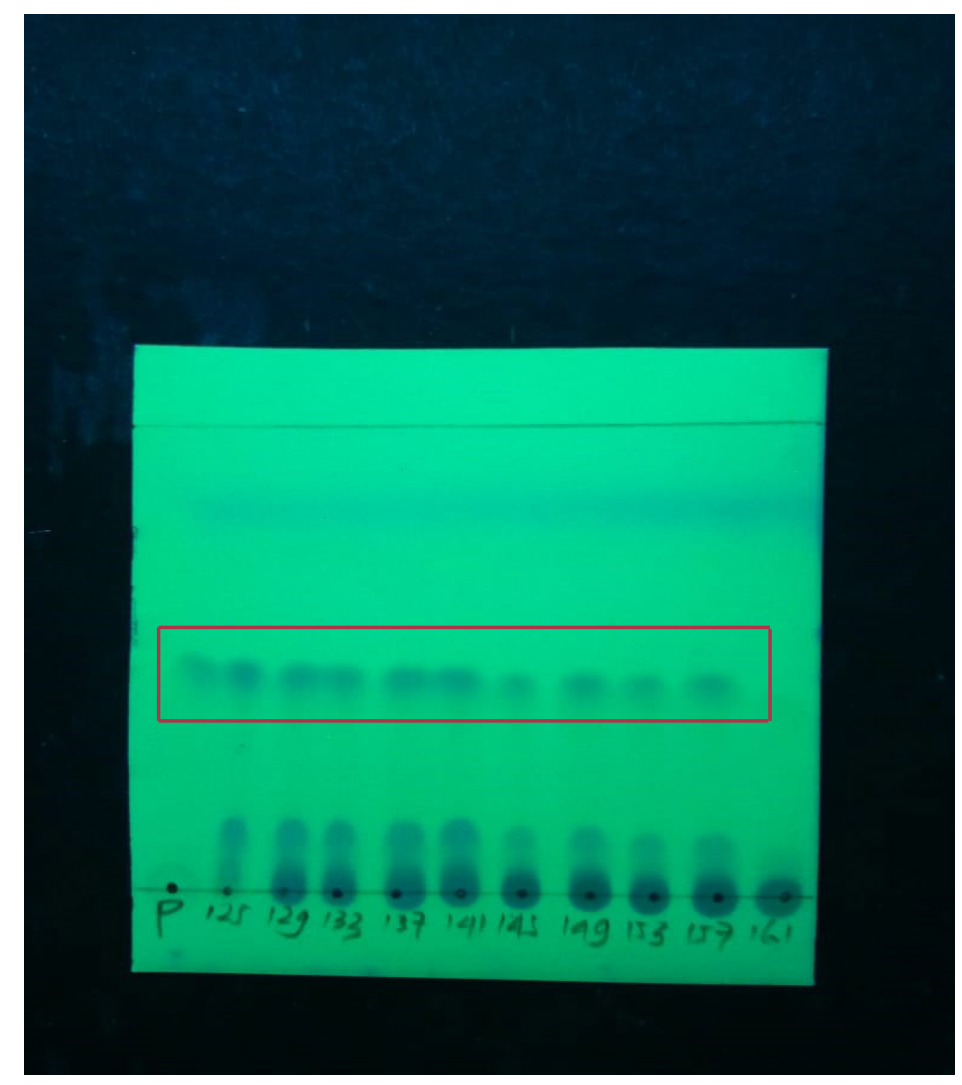

Gambar 1. Pola KLT ekstrak terpurifikasi daun surian dan pembanding metil galat dengan eluen $n$-heksan: etil asetat $(2: 3) \mathrm{Rf}=0,57$. 
Tabel 1. Pengaruh variasi konsentrasi senyawa $\alpha$-mangostin dan persen inhibisi radikal bebas DPPH

\begin{tabular}{llc}
\hline \multicolumn{1}{c}{ Fraksi etil asetat (g) } & \multicolumn{1}{c}{ Randemen $(\mathbf{g})$} & \% Randemen \\
\hline 50 & 11,851 (ekstrak terpurifikasi) & $23,702 \%$ \\
\hline Rumus randemen & $\begin{array}{l}\text { B } / \text { A }) \text { X } 100 \% \\
\text { Keterangan }\end{array}$ & $\begin{array}{l}\text { A : berat fraksi etil asetat } \\
\text { B : berat ekstrak terpurifikasi yang diperoleh }\end{array}$
\end{tabular}

Tabel 2. Hasil pengukuran kadar nitrogen monoksida (NO) serum

\begin{tabular}{crrrrr}
\hline \multirow{2}{*}{ Tikus } & KP & KN & D1 & D2 & D3 \\
\cline { 2 - 6 } & 42,575 & 46,951 & 42,58 & 55,08 & 38,320 \\
\hline 1 & 17,421 & 48,829 & 50,71 & 38,51 & 45,702 \\
2 & 34,130 & 51,956 & 40,39 & 40,39 & 34,444 \\
4 & 26,700 & 44,451 & 50,39 & 34,76 & 48,204 \\
5 & 38,890 & 47,140 & 50,58 & 33,82 & 34,757 \\
Rata-rata \pm SD & $31,94^{\mathrm{a}} \pm 10,06$ & $47,86^{\mathrm{b}} \pm 2,77$ & $46,92^{\mathrm{b}} \pm 5,03$ & $40,51^{\mathrm{a}, \mathrm{b}} \pm 8,58$ & $40,28^{\mathrm{a}, \mathrm{b}} \pm 6,30$ \\
\hline
\end{tabular}

Keterangan:

a dan $\mathrm{b} \quad$ : Nilai dengan superscrib yang berbeda menunjukkan perbedaan nyata $\mathrm{P}<0,05$.

KP : Kontrol Positif

KN : Kontrol Negatif

D1 : Ekstrak Terpurifikasi Daun Surian Dosis $5 \mathrm{mg} / \mathrm{kg} \mathrm{BB}$

D2 : Ekstrak Terpurifikasi Daun Surian Dosis $10 \mathrm{mg} / \mathrm{kg}$

D3 : Ekstrak Terpurifikasi Daun Surian Dosis $20 \mathrm{mg} / \mathrm{kg}$

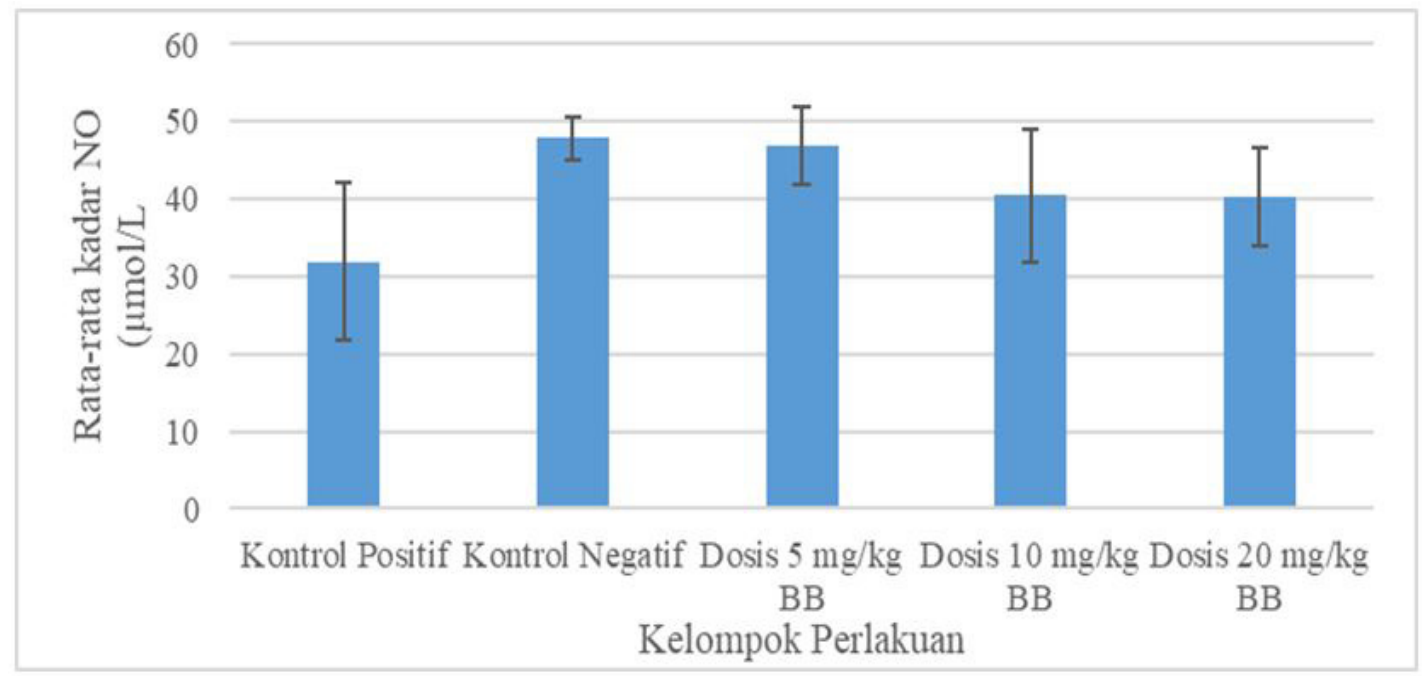

Gambar 2. Hubungan antara perlakuan dengan rata-rata konsentrasi NO. 
Tabel 3. Hasil Pengukuran Rasio Berat Organ Hati

\begin{tabular}{crrrrr}
\hline & \multicolumn{5}{c}{ Rasio Berat Organ Hati } \\
\cline { 2 - 6 } Tikus & KP & KN & D1 & D2 & D3 \\
\hline 1 & 6,948 & 5,811 & 5,242 & 4,763 & 7,688 \\
2 & 6,904 & 6,146 & 6,554 & 6,527 & 5,273 \\
3 & 6,849 & 6,735 & 6,673 & 7,341 & 5,676 \\
4 & 7,564 & 5,582 & 5,547 & 6,579 & 5,526 \\
5 & 5,945 & 5,857 & 4,032 & 6,600 & 5,000 \\
& 3,16800 & 3,12691 & 3,15342 & 3,07461 & 3,43059 \\
Rata-rata \pm SD & \pm & \pm & \pm & \pm & \pm \\
& 0,12909 & 0,27623 & 0,64176 & 0,24493 & 0,45068 \\
\hline
\end{tabular}

Keterangan:

SD : Standar Deviasi.

KP : Kontrol Positif

KN : Kontrol Negatif

D1 : Ekstrak Terpurifikasi Daun Surian Dosis $5 \mathrm{mg} / \mathrm{kg} \mathrm{BB}$

D2 : Ekstrak Terpurifikasi Daun Surian Dosis $10 \mathrm{mg} / \mathrm{kg}$

D3 : Ekstrak Terpurifikasi Daun Surian Dosis $20 \mathrm{mg} / \mathrm{kg}$

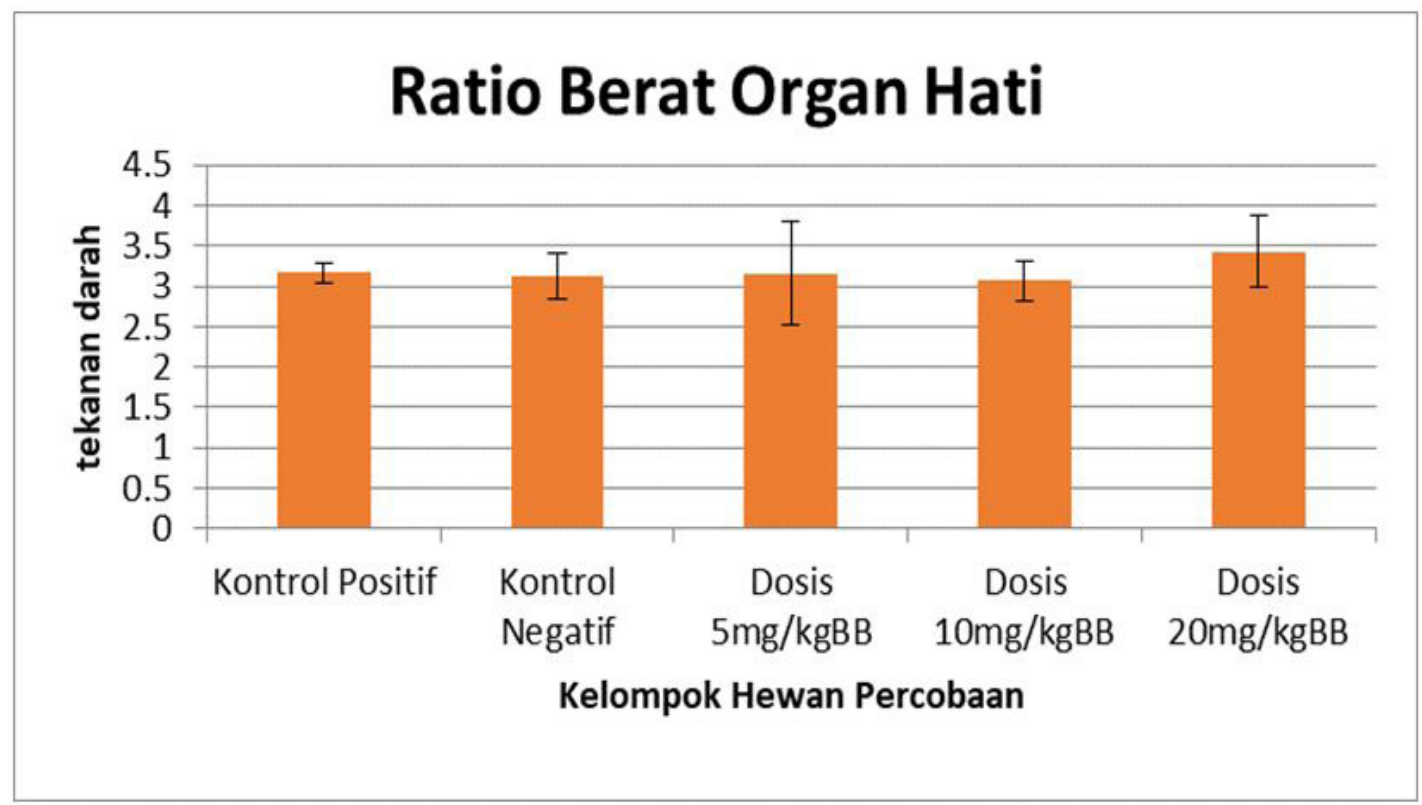

Gambar 3. Hubungan Kelompok Perlakuan Dengan Rasio Berat Organ Hati.

b. Rasio berat organ ginjal

Rata-rata berat organ ginjal tikus kelompok kontrol positif $(0,676 \pm 0,066)$, kontrol negatif $(0,604 \pm 0,044)$, dosis $5 \mathrm{mg} / \mathrm{kg} \mathrm{BB}(0,649 \pm 0,188)$, dosis $10 \mathrm{mg} / \mathrm{kg} \mathrm{BB}$ $(0,660 \pm 0,086)$, dan dosis $20 \mathrm{mg} / \mathrm{kg} \mathrm{BB}(0,668 \pm 0,119)$. Berdasarkan analisa secara statistik, pemberian ekstrak terpurifikasi daun surian tidak memberikan pengaruh terhadap rasio berat organ ginjal tikus uji $(p>0,05)$ (Tabel 4 dan gambar 4). c. Rasio berat organ jantung

Rata-rata berat organ hati tikus kelompok kontrol positif $(0,339 \pm 0,034)$, kontrol negatif $(0,353 \pm 0,020)$, dosis $5 \mathrm{mg} / \mathrm{kg} \mathrm{BB}(0,324 \pm 0,036)$, dosis $10 \mathrm{mg} / \mathrm{kg} \mathrm{BB}$ $(0,333 \pm 0,023)$, dan dosis $20 \mathrm{mg} / \mathrm{kg} \mathrm{BB}(0,329 \pm 0,007)$. Berdasarkan analisa secara statistik, pemberian ekstrak terpurifikasi daun surian tidak memberikan pengaruh terhadap rasio berat organ jantung tikus uji $(\mathrm{p}>0,05)$ (Tabel 5). 
Tabel 4. Hasil Pengukuran Rasio Berat Organ Ginjal

\begin{tabular}{crrrrr}
\hline \multirow{5}{*}{ Tikus } & \multicolumn{5}{c}{ Rasio Berat Organ Ginjal } \\
\cline { 2 - 6 } & KP & KN & D1 & D2 & D3 \\
\hline 1 & 1,463 & 1,078 & 1,007 & 1,306 & 1,495 \\
2 & 1,635 & 1,185 & 1,54 & 1,371 & 1,047 \\
3 & 1,405 & 1,254 & 1,15 & 1,462 & 0,900 \\
4 & 1,511 & 1,134 & 1,16 & 1,403 & 1,198 \\
5 & 1,265 & 1,168 & 0,86 & 1,199 & 1,021 \\
& 0,676 & 0,604 & 0,649 & 0,659 & 0,668 \\
Rata-rata \pm SD & \pm & \pm & \pm & \pm & \pm \\
& 0,066 & 0,044 & 0,188 & 0,086 & 0,119 \\
\hline
\end{tabular}

Keterangan:

SD : Standar Deviasi.

KP : Kontrol Positif

KN : Kontrol Negatif

D1 : Ekstrak Terpurifikasi Daun Surian Dosis $5 \mathrm{mg} / \mathrm{kg} \mathrm{BB}$

D2 : Ekstrak Terpurifikasi Daun Surian Dosis $10 \mathrm{mg} / \mathrm{kg}$

D3 : Ekstrak Terpurifikasi Daun Surian Dosis $20 \mathrm{mg} / \mathrm{kg}$

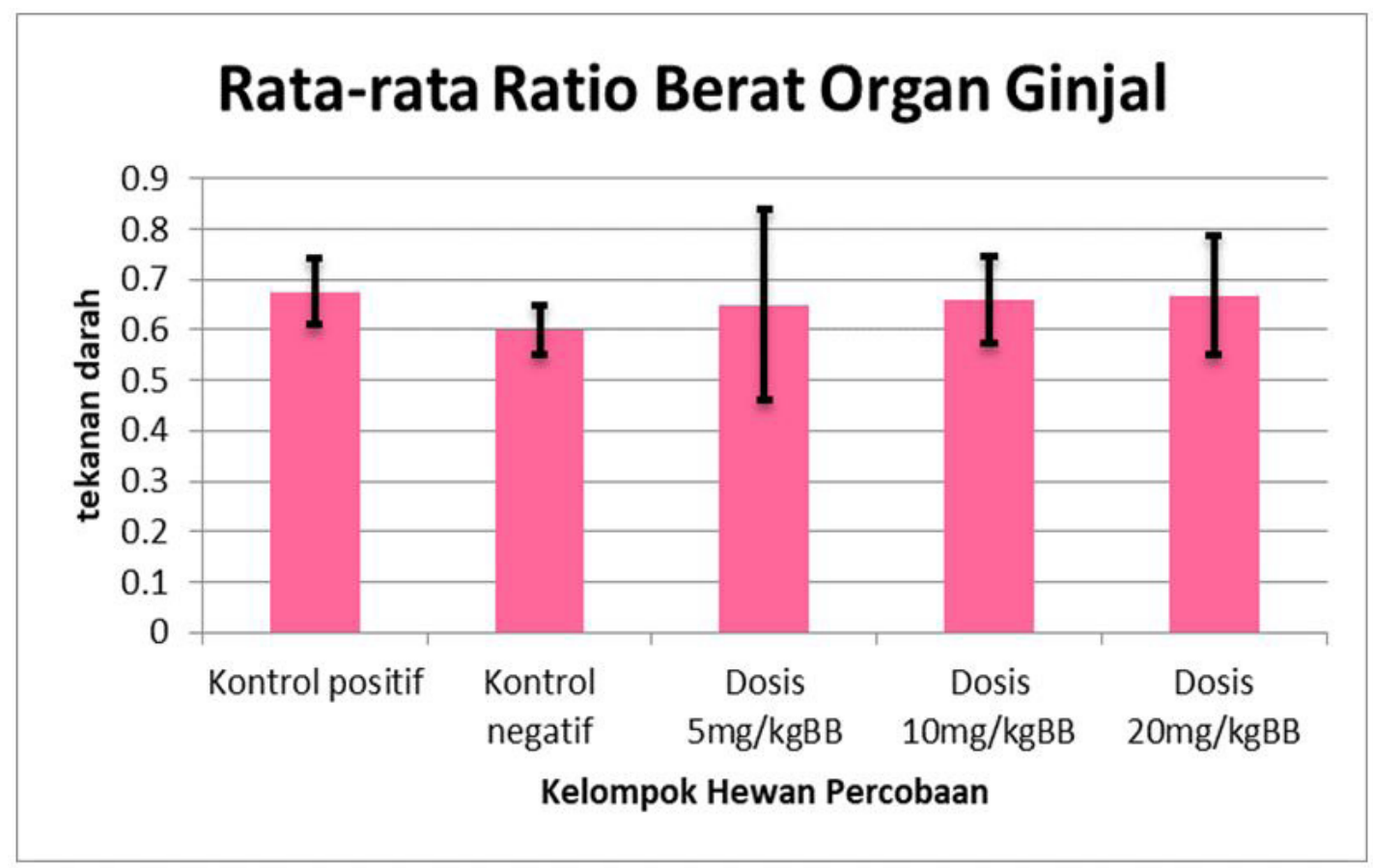

Gambar 4. Hubungan Kelompok Perlakuan Dengan Rasio Berat Organ Ginjal.

\section{Pembahasan}

Untuk mendapatkan ekstrak terpurifikasi fraksi etil asetat terpurifikasi dengan kromatografi kolom menggunakan fasa diam silika gel dan fasa gerak n-heksan, diklorometan, etil asetat, dan metanol dengan kepolaran yang ditingkatkan (SGP). Hasil kolom di monitor dengan KLT dan lampu UV $254 \mathrm{~nm}$. Identifikasi kualitatif ekstrak terpurifikasi T. sureni dilakukan dengan metode KLT. Fase diam yang digunakan pada KLT adalah silika gel SF 60 yang bersifat Polar, sedangkan fase gerak yang digunakan adalah n-heksan:etil asetat (2:3) v/v. Standar yang digunakan adalah metil galat murni. Ekstrak terpurifikasi (11,851 gram) menunjukkan nilai Rf yang sama dengan metil galat pada plat KLT silika gel. Nilai Rf yang ditunjukkan dari plat KLT adalah 0,57 (gambar 1), selanjutnya ekstrak terpurifikasi dilakukan identifikasi secara organoleptis, 
fisika, kimia.

Hasil pengujian kualitatif menunjukkan bahwa ekstrak terpurifikasi daun surian mengandung metil galat, selanjutnya dilakukan pengujian kuantitatif kandungan metil galat dalam ekstrak terpurifikasi menggunakan metode KLT-densitometri. Metode ini dipilih karena metil galat memiliki gugus kromofor yang bertanggung jawab pada penyerapan sinar UV. Prinsip metode ini yaitu membandingkan kerapatan kromatogram senyawa uji yang telah dipisahkan dan diukur dengan kerapatan kromatogram senyawa standar. Sebelum melakukan pengujian dengan KLT densitometer, terlebih dahulu dilakukan pengukuran panjang gelombang maksimum standar metil galat menggunakan spektrofotometer UVVis. Diperoleh panjang gelombang maksimum metil galat pada $275 \mathrm{~nm}$, panjang gelombang ini yang akan digunakan untuk mengukur AUC standar metil galat dan AUC sampel. Berdasarkan analisis secara kuantitatif ini dapat diketahui bahwa dalam 100 gram ekstrak terpurifikasi daun surian terdapat 0,01132 gram metil galat. Kandungan metil galat dalam ekstrak terpurifikasi daun surian inilah yang diduga mampu memproteksi disfungsi sel endotel karena memiliki aktivitas sebagai antioksidan [7].
Penginduksi yang digunakan dalam disfungsi sel endotel hewan uji adalah $\mathrm{NaCl}$ dipilih sebgai penginduksi karena diketahui bahwa konsumsi garam yang tinggi (20-23 $\mathrm{g} /$ hari) pada manusia dapat menurunkan kadar NO dalam darah [10]. Konsentrasi $\mathrm{NaCl}$ yang digunakan yaitu $3 \%$, dimana pemberian garam dengan konsentrasi tersebut dapat meningkatkan tekanan darah hewan uji dan memicu terjadinya disfungsi sel endotel. Keadaan hipertensi dapat meningkatkan produksi anion superoksida juga mampu merusak dan menghancurkan NO sehingga menurunkan kadar NO [11].

Pemeriksaan kadar NO dilakukan dengan menggunakan Quanti Chrom Nitric Oxide Assay Kit dan alat ELISA Spektrofotometer Bio-Rad®. Pengujian dengan metode ELISA ini menggunakan reagen GRIESS I dan GRIESS II yang akan menghasilkan garam diazonium ditandai dengan terbentuknya warna pink. Hasil penelitian telah terjadi disfusngsi sel endotel yang diinduksian $\mathrm{NaCl} 3$ $\%$ dapat ditandai dengan terjadinya penurunan kadar NO yang ditunjukkan rendahnya kadar NO pada kelompok kontrol positif $(31,943 \mu \mathrm{mol} / \mathrm{L})$ jika dibandingkan dengan kelompok kontrol negatif $(47,865 \mu \mathrm{mol} / \mathrm{L})$ (Tabel 2 dan gambar 2). Pada kelompok kontrol negatif tidak diberi $\mathrm{NaCl} 3 \%$ tidak terjadi disfungsi sel endotel.

Tabel 5. Hasil Pengukuran Rasio Berat Organ Jantung

\begin{tabular}{|c|c|c|c|c|c|}
\hline \multirow{2}{*}{ Tikus } & \multicolumn{5}{|c|}{ Rasio Berat Organ Jantung } \\
\hline & KP & KN & D1 & D2 & D3 \\
\hline 1 & 0,693 & 0,706 & 0,631 & 0,616 & 0,611 \\
\hline 2 & 0,825 & 0,679 & 0,596 & 0,787 & 0,568 \\
\hline 3 & 0,652 & 0,708 & 0,612 & 0,705 & 0,563 \\
\hline 4 & 0,814 & 0,633 & 0,533 & 0,617 & 0,538 \\
\hline \multirow[t]{2}{*}{5} & 0,674 & 0,676 & 0,510 & 0,705 & 0,506 \\
\hline & 0,339 & 0,353 & 0,324 & 0,333 & 0,329 \\
\hline \multirow[t]{2}{*}{ Rata-rata \pm SD } & \pm & \pm & \pm & \pm & \pm \\
\hline & 0,033 & 0,020 & 0,035 & 0,023 & 0,007 \\
\hline
\end{tabular}

Keterangan:

SD : Standar Deviasi.

KP : Kontrol Positif

KN : Kontrol Negatif

D1 : Ekstrak Terpurifikasi Daun Surian Dosis $5 \mathrm{mg} / \mathrm{kg} \mathrm{BB}$

D2 : Ekstrak Terpurifikasi Daun Surian Dosis $10 \mathrm{mg} / \mathrm{kg}$

D3 : Ekstrak Terpurifikasi Daun Surian Dosis $20 \mathrm{mg} / \mathrm{kg}$ 


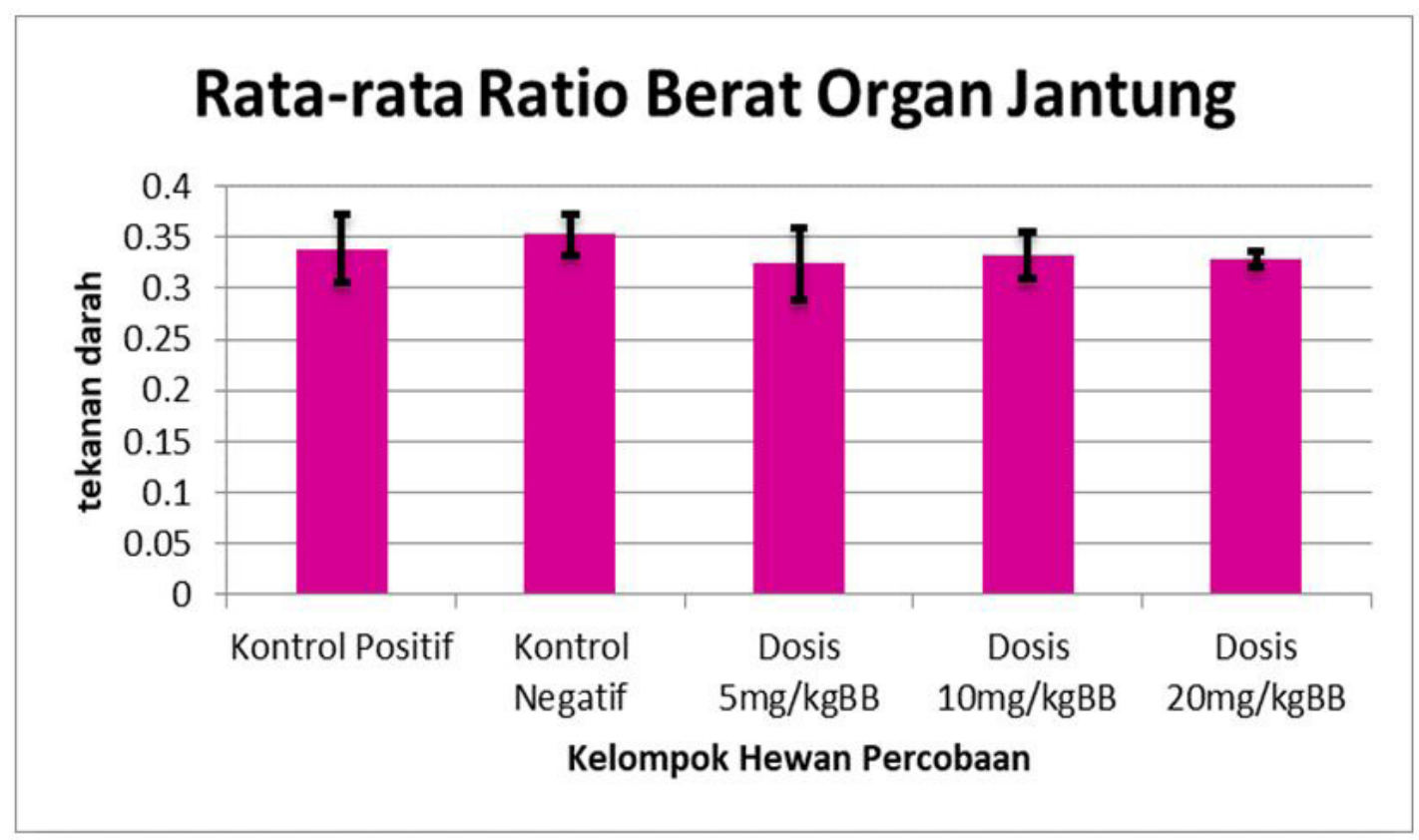

Gambar 5. Hubungan Kelompok Perlakuan Dengan Rasio Berat Organ Jantung.

Penentuan adanya aktivitas proteksi disfungsi sel endotel dari ekstrak terpurifikasi T. sureni ditandai dengan meningkatnya kadar NO pada kelompok dosis 5 $\mathrm{mg} / \mathrm{kg} \mathrm{BB}$, dosis $10 \mathrm{mg} / \mathrm{kg} \mathrm{BB}$, kelompok dosis $20 \mathrm{mg} /$ $\mathrm{kg}$ BB dibandingkan dengan kadar NO kelompok kontrol positif. Dari hasil yang diperoleh, dapat diperkirakan bahwa pemberian ekstrak terpurifikasi T. sureni mampu memproteksi terjadinya disfungsi sel endotel karena ekstrak ini mengandung metil galat yang bersifat anti oksidan. Selain itu ekstrak terpurifikasi T. sureni diduga mengandung zat aktif yang dapat meningkatkan asetil kolin. Asetil kolin dapat mempengaruhi aktivasi enzim nitrit oksida sintase sehingga meningkatkan produksi NO dari L-arginin serta meningkatkan produksi prostaglandin [12].

Berdasarkan hasil data analisa varian (ANOVA) yang membandingkan nilai rata-rata kadar NO kelompok kontrol positif dengan kelompok kontrol negatif, dosis 5 $\mathrm{mg} / \mathrm{kg} \mathrm{BB}$, dosis $10 \mathrm{mg} / \mathrm{kg} \mathrm{BB}$, dan dosis $20 \mathrm{mg} / \mathrm{kg} \mathrm{BB}$ didapatkan nilai signifikansi $\mathrm{p}<0,05$. Nilai ini menunjukkan adanya perbedaan yang nyata antara kadar NO tiap-tiap kelompok perlakuan. Pada analisa uji lanjut Duncan, nilai rata-rata kadar NO kelompok kontrol negatif dan dosis 5 $\mathrm{mg} / \mathrm{kg}$ BB menunjukkan hasil yang berbeda nyata dengan kelompok kontrol positif $\mathrm{p}<0,05$, sedangkan nilai ratarata kadar NO kelompok dosis $10 \mathrm{mg} / \mathrm{kg}$ BB dan dosis 20 $\mathrm{mg} / \mathrm{kg}$ BB lebih tinggi jika dibandingkan dengan kelompok kontrol positif tetapi perbedaannya tidak bermakna karena $\mathrm{p}<0,05$. Nilai rata-rata kadar NO kelompok dosis $10 \mathrm{mg} /$ $\mathrm{kg}$ BB dan dosis $20 \mathrm{mg} / \mathrm{kg}$ BB sama kelompok kontrol negatif yang menandakan bahwa kedua dosis ini memiliki efek dalam meningkatkan kadar NO (Tabel 3).

Dari hasil penelitian yang telah dilakukan menunjukkan bahwa variasi pemberian dosis ekstrak terpurifikasi daun surian dosis $5 \mathrm{mg} / \mathrm{kg} \mathrm{BB}$, dosis $10 \mathrm{mg} /$ $\mathrm{kg} \mathrm{BB}$, dan dosis $20 \mathrm{mg} / \mathrm{kg}$ BB menunjukkan peningkatan nilai rata-rata kadar NO serum. Dosis $5 \mathrm{mg} / \mathrm{kg} \mathrm{BB}$ merupakan dosis yang paling efektif diantara variasi dosis lainnya karena memberikan peningkatan rata-rata kadar NO serum tertinggi dibandingkan dengan dosis $10 \mathrm{mg} / \mathrm{kg}$ BB dan dosis $20 \mathrm{mg} / \mathrm{kg} \mathrm{BB}$.

Pada penelitian ini juga dilakukan pengukuran rasio berat organ hati, jantung, dan ginjal hewan uji. Penentuan rasio berat organ berguna untuk melihat apakah pemberian ekstrak terpurifikasi daun surian selama 21 hari akan memberikan efek terhadap organ tersebut. Hasil analisa statistik terhadap rasio berat organ hati, jantung, dan ginjal tidak menunjukkan perbedaan yang nyata $(p>0,05)$ ( $\underline{\text { Tabel } 3}, \underline{4}, \underline{5}$ dan gambar 3 , 4) yang menandakan pemberian ekstrak terpurifikasi T. sureni selama 21 hari tidak mempengaruhi organ hati, jantung, dan ginjal hewan uji. Pemberian ekstrak terpurifikasi daun surian dalam jangka waktu lama tidak menimbulkan gangguan pada organ hati, jantung, dan ginjal dan aman digunakan. 


\section{Kesimpulan}

Dari hasil penelitian pengaruh ekstrak terpurifikasi T. sureni terhadap disfungsi sel endotel yang diinduksi prednison dan $\mathrm{NaCl}$, dapat diambil kesimpulan sebagai berikut:

Pemberian ekstrak terpurifikasi T. sureni dapat memproteksi disfungsi sel endotel yang diinduksi kombinasi Prednison- $\mathrm{NaCl}$. Dosis $5 \mathrm{mg} / \mathrm{kg}$ BB memberikan hasil yang paling baik dibandingkan dengan dosis $10 \mathrm{mg} / \mathrm{kg}$ BB dan $20 \mathrm{mg} / \mathrm{kg}$ BB. Pemberian ekstrak terpurifikasi T. sureni tidak mempengaruhi rasio berat organ hewan uji ( $\mathrm{p}$ $>0,05)$.

\section{Ucapan Terimakasih}

Penulis mengucapkan terimakasih kepada Fakultas Farmasi Universitas Andalas atas bantuan dana riset Dipa Fakultas no. 24/UN.16.10/DPPKM/FFARMASI/2018.

\section{Referensi}

[1] noe N., and Nishida K., 1998, Probucol Improves EndothelialDependet Relaxation and Decreases Vascular Superoxide Production In Cholesterol-Fed Rabbits, American Journal Of the Medical Sciences.242-247.

[2] Cooke, JP, 1997, Theraupetics Interventions in Endhotelial Dysfunction, Endhotelium as Target Organ, Jurnal Clin Cardiol, Vol. 2, No.2, Hal. 45-51.
[3] Jawi, I. M., \& Yasa, W. P. S. (2012). Ekstrak Air Umbi Ubi Jalar Ungu Menurunkan Tekanan Darah Mencit Putih Hipertensi Yang diinduksi dengan $\mathrm{NaCl}$. J. Medicina., 43(2), 72-76.

[4] Saidu, Y., Bilbis, L.S., Muhammad, S.A., \& Nasir, M.K. (2012). Serum Lipid Profile and Antioxidant Status of Salt-Induced Hypersensitive Rats Treated with Antioxidants Rich Nutraceutical. Cameroon. J. Exp. Biol, 8,(1), 47-54.

[5] Chataigneau, T., Michel, F.I., Paul L.H., Mark, C.F., Jacques, D., \& Paul, M.V. 1999. Acetylcholine-Induced Relaxation in Blood Vessels From Endothelial Nitric Oxide Synthase Knockout Mice. Br. J. Pharmacol., 126(1), 219-226.

[6] Kraus WK. dan K. Kypke. Surenone and Surenin, Two Novel Essentials Tetratriterpenoid from Toona sureni (BL) Merr, Tetrahedron Letter. 1979;(29):2715-2716.

[7] Ekaprasada MT, Nurdin H, Ibrahim S, Dachriyanus. Antioxidant Activity Of Methyl Gallate Isolated From The Leaves Of Toona Sureni. Indo. J. Chem. 2009;9(3):457-460.

[8] Ekaprasada, M.T., Hazli, N., Sanusi, I., \&. Dachriyanus. (2013). “ Antibacterial Activity Of Methyl Gallate Isolated from The Leaves of Toona Sureni". The Indonesia Society for Biomaterial Chemistry J.Biomatchem. 1(1-6).

[9] Suhatri, Arifin, H., dan Hadira, F. L. I. 2009. Efek Proteksi Ekstrak Daun Surian (Toona Sureni (BI.) Merr) Terhadap Gangguan Fungsi Sel Endotel Pembuluh Darah Tikus. Jurnal Sains dan Teknologi Farmasi, 14 (2): 17-24.

[10] Fujiwara, N., Osanai, T., Kamada, T., Katoh, T., Takahashi, K., \& kumura, K. (2000). Study on The Relationship Between Plasma Nitrite Andnitrate Level and Salt Sensitivity in Human Hypertension Modulation of Nitric Oxide Synthesis by Salt Intake. J. Circ. 101,(8), 856-861.

[11] Versari D, Daghini E, Virdis A, Ghiadoni L, dan Taddei S. EndhoteliumDependent Constractions and Endhotelial Dysfunction in Human Hypertension. British Journal of Pharmacology. 2009;157:527-536.

[12] Kellog DL Jr, Zhao JL, Coey U, dan Green JV. Acetylcholine-induced Vasodilation si Mediated by Nitric Oxide and Prostaglandins in Human Skin. J Appl Physiol. 1985;98:629-632.

Copyright $\odot 2019$ The author(s). You are free to share (copy and redistribute the material in any medium or format) and adapt (remix, transform, and build upon the material for any purpose, even commercially) under the following terms: Attribution - You must give appropriate credit, provide a link to the license, and indicate if changes were made. You may do so in any reasonable manner, but not in any way that suggests the licensor endorses you or your use; ShareAlike - If you remix, transform, or build upon the material, you must distribute your contributions under the same license as the original (https://creativecommons.org/licenses/by-sa/4.0/) 